\title{
AUDIT ENERGI DALAM PENGOLAHAN KARET
}

\author{
Energy Audit in the Natural Rubber Processing \\ Didin Suwardin, Mili Purbaya dan Afrizal Vachlepi \\ Balai Penelitian Sembawa - Pusat Penelitian Karet \\ J1. Raya Palembang - Betung Km. 29.Kotak Pos 1127 Palembang 30001 \\ Email : dsuwardin04@yahoo.com
}

Diterima 17 Desember 2015/ Direvisi 1 Juni 2016/ Disetujui 17 Juni 2016

\begin{abstract}
Abstrak
Penggunaan energi di Indonesia dinilai masih belum efisien, hal ini ditunjukkan dengan nilai elastisitas energi dan intensitas energi masing-masing sebesar 2,69 dan 565 ton-oil-equivalent per 1 juta USD (International Energy Agency, 2009). Audit energi merupakan salah satu upaya untuk mengevaluasi pemanfaatan energi dan mengidentifikasi peluang penghematan energi serta rekomendasi peningkatan efisiensi pada pengguna energi dan pengguna sumber energi dalam rangka konservasi energi. Penerapan audit energi dilakukan untuk semua sektor industri di Indonesia, termasuk industri pengolahan karet. Industri pengolahan karet remah merupakan industri yang banyak mengkonsumsi energi, dimana total kosumsi energi sebesar 26.257.005 kWh dengan produksi sebesar 45.240 ton. Korelasi konsumsi energi $(\mathrm{Y})$ dengan produksi $(\mathrm{X})$ adalah $\mathrm{Y}=455+154 \mathrm{X}$ dengan koefisien determinasi $\left(\mathrm{r}_{\mathrm{XY}}\right)=0,9$. Potensi penghematan energi yang dapat dilakukan, diantaranya adalah efisiensi pada peralatan utama pengguna energi, efisiensi pada peralatan utilitas dan pelaksanaan sistem manajemen energi. Selain itu, konversi bahan bakar fosil ke sumber energi terbarukan dan ramah lingkungan juga dapat diterapkan dalam rangka konservasi energi.
\end{abstract}

Kata kunci: audit, energi, karet remah, pengolahan

\begin{abstract}
The usage of energy in Indonesia is still inefficient, this fact showed with value of elasticity and intensity energy was 2.69 and 565 ton-oilequivalentper 1 juta USD (International Energy Agency, 2009) respectively. The audit energy is one method to evaluate the energy used and identified of opportunities for energy savings and recommendations for improving the efficiency of the energy used in order to conserve energy. The implementation of an energy audit conducted for all sectors of industry in Indonesia, including the rubber processing industry. The crumb rubber factory is an industry which consumes energy in a large amount, the total energy consumption is 26,257,005 $\mathrm{kWh}$ with 45,240 tonnes of total production. The correlation between energy consumption ( $Y$ ) and production $(X)$ is $Y=455+$ $154 X$ where $r_{X Y}=0.9$. The potential of energy savings could be done, including the efficiency of the main equipments of energy users, the efficiency ofutility equipment, and implementing energy management system. In addition, the conversion of fossil energy to renewable energy and environmental friendly energy can also be applied in order to conserve energy.
\end{abstract}

Keywords: audit, energy, processing, crumb rubber

\section{Pendahuluan}

Indonesia memiliki sumber daya energi fosil utama seperti batubara, minyak dan gas bumi, tetapi sejak 2012 terjadi penurunan sumber daya energifosil tersebut. Sumber daya 
energi batubara mengalami penurunan menjadi 119 milliar ton dengan cadangan sebesar 29 milliar ton. Sedangkan minyak bumi memiliki cadangan sebesar 7,41 milyar barel yang terdiri atas 3,74 milyar barel cadangan terbukti dan 3,67 milyar barel cadangan potensial. Sementara itu, gas bumi memiliki cadangan sebesar 151 TSCF yang terdiri atas 103 TSCF cadangan terbukti dan 47 TSCF cadangan potensial (Anindhita, 2014).

Berdasarkan rasio cadangan terhadap produksi untuk masing-masing sumber energi fosil tersebut, sumber energi batubara memiliki potensi yang paling tinggi, yaitu sekitar 75 tahun, sedangkan sumber energi gas dan minyak bumi, masing-masing memiliki potensi 33 dan 12 tahun, jika tidak ditemukan cadangan baru (Anindhita, 2014). Dengan semakin terbatasnya ketersediaan sumber energi fosil di Indonesia maka perlu dilakukan upaya pemanfaatan energi secara bijak dan efisien, serta pemanfaatan sumber energi baru dan terbarukan seperti tenaga air, panas bumi, surya, angin, samudera maupun biomassa.

Menurut data dari International Energy Agency (IEA), pada tahun 2009, Indonesia memiliki intensitas energi (jumlah konsumsi energi/produksi domestik bruto) yang tinggi yaitu 565 TOE (ton-oil-equivalent) per 1 juta USD, sedangkan elastisitas energi Indonesia adalah 2,69. Sebagai perbandingan negaranegara maju memiliki intensitas $164 \mathrm{TOE} / \mathrm{juta}$ USD dan elastisitas berkisar dari 0,1 - 0,6 (Save Energy, 2012). Angka intensitas dan elastisitas energi di Indonesia relatif tinggi jika dibandingkan dengan negara-negara maju, ini menunjukkan bahwa pemakaian energi di Indonesia masih belum efisien.

Dalam rangka pemanfaatan energi yang efisien di Indonesia, terutama untuk industri pengolahan karet diperlukan suatu kegiatan audit energi untuk mengevaluasi pemanfaatan energi dan identifikasi peluang penghematan energi serta rekomendasi peningkatan efisiensi pada industri. Tulisan ini akan membahas mengenai manajemen energi, audit energi dan aplikasinya dalam industri pengolahan karet, terutama pabrik pengolahan karet remah, karena industri karet remah mendominasi industri pengolahan karet alam di Indonesia.
Selain itu akan disampaikan juga peluangpeluang penghematan energi dan konversi energi fosil dengan energi terbarukan.

\section{Audit Energi}

Langkah awal pelaksanaan manajemen energi adalah audit energi. Audit energi merupakan kegiatan untuk mengidentifikasi titik-titik pemborosan energi yang terjadi pada suatu sistem pemanfatan energi, merencanakan, menganalisis dan merekomendasikan langkah-langkah dalam meningkatkan efisiensi energi (Ayuni, 2012).

Kebijakan-kebijakan audit energi adalah :

1. Inpres No. 9 tahun 1982 tentang Konservasi Energi

2. Keppres No. 43 tahun 1991 tentang Konservasi Energi

3. Inpres No.10 tahun 2005 tentang Penghematan Energi

4. Permen ESDM No. 31 tahun 2005 tentang Tata Cara Pelaksanaan Penghematan Energi

5. Rencana Induk Konservasi Nasional (RIKEN) tahun 1995 dan Revisinya tahun 2005

6. Perpres No. 5 tahun 2006 tentang Kebijakan Energi Nasional

7. Inpres No. 1 tahun 2006 tentang Penyediaan dan Pemanfaatan Bahan Bakar Nabati (Biofuel)

8. UU No. 30 tahun 2007 tentang Energi

9. PP No. 70 tahun 2009 tentang konservasi energi

Dalam pelaksanaan audit energi terdapat beberapa sasaran yang ingin dicapai, yaitu:

1. Menurunnya intensitas penggunaan energi di industri.

2. Meningkatkan peran serta industri dalam program konservasi energi.

3. Pengurangan ketergantungan terhadap BBM.

4. Pengurangan pencemaran yang dapat merusak kualitas lingkungan.

5. Peningkatan daya saing produk.

6. Peningkatan efisiensi penggunaan energi dalam berproduksi.

Hasil audit energi memberikan dampak 
nyata dalam usaha penghematan energi, seperti pada hasil audit energi pada bangunan dimana potensi penghematan energi dapat dilakukan diantaranya dengan penggantian AC konvensional dengan AC inverter, penggunaan lampu hemat energi (LHE) seperti lampu LED (Marzuki dan Rusman, 2012; Raharjo et al., 2014). Sedangkan peluang penghematan energi dari hasil audit energi pada kelistrikan, diantaranya pemasangan filter aktif maupun pasif pada alat-alat listrik non-linier, peningkatan faktor daya (Mulyadi et al., 2013; Palaloi, 2005).

Audit energi memberi banyak manfaat, diantaranya :

a. Saving money

Dengan adanya manajemen energi, dapat mengurangi biaya operasional. Dengan demikian keuntungan yang diperoleh perusahaan akan meningkat.

\section{b. Environmental protection}

Dengan adanya penggunaan energi yang efisien maka akan memberikan kontribusi bagi dunia dalam hal membantu pelestarian alam dengan menjaga dan mempertahankan cadangan minyak bumi dunia agar tidak segera habis.

c. Sustainable development

Dengan adanya penggunaan energi yang efisien maka akan memberikan kontribusi bagi perusahaan di bidang pertumbuhan yang berkelanjutan baik di sisi finansial maupun penggunaan peralatan industri yang memiliki lifetime maksimum/optimum.

\section{Jenis Audit Energi}

\section{a. AuditEnergi Awal (AEA)}

AEA sangat berguna untuk mengenali sumber-sumber pemborosan energi dan tindakan-tindakan sederhana yang dapat diambil untuk meningkatkan efisiensi energi dalam jangka pendek.

AEA terdiri dari dua bagian, yaitu:

1. Survei manajemen energi

Auditor energi mencoba untuk memahami kegiatan manajemen yang sedang berlangsung dan kriteria putusan investasi yang mempengaruhi proyek konservasi.

\section{Survei energi (teknis)}

Bagian ini mengulas kondisi dan operasi peralatan dari pemakai energi yang penting (misalnya boiler dan sistem uap) serta instrumentasi yang berkaitan dengan efisiensi energi.

\section{b. Audit Energi Terinci (AET)}

AET dilakukan setelah AEA. Audit ini dilakukan dengan cara mengumpulkan data pabrik dari catatan yang ada, mengukur parameter operasi yang penting dengan instumentasi portable untuk mengaudit energi dalam neraca material dan panas pada peralatan proses. Jenis uji yang dijalankan mencangkup uji efisiensi pembakaran, pengukuran suhu dan aliran udara pada peralatan utama yang menggunakan bahan bakar, penentuan penurunan faktor daya yang disebabkan oleh berbagai peralatan listrik dan uji sistem proses untuk operasi yang masih di dalam spesifikasi.

\section{Metode Audit Energi}

Untuk mencapai sasaran-sasaran audit energi, terdapat beberapa metode yang dapat digunakan dalam pelaksanaan audit energi, yaitu:

a. Goal Seek Method

Intensitas Konsumsi Energi (IKE) merupakan parameter utama yang harus dicari dan ditentukan, baik pada sistem proses produksi maupun pada peralatan utility (boiler, chiller, compressor, pompa, dil). Dengan besaran/nilai IKE tersebut dapat dikembangkan menjadi formulasi dan simulasi analisis peluang penghematan energi.

\section{b. Pareto Chart}

Grafik Pareto dapat digunakan untuk menentukan permasalahan utama atau identifikasi masalah inti. Mekanisme pendekatan masalah menggunakan grafik ini adalah :

1. Menentukan karakteristik mutu, misalnya teknologi pengguna energi terbesar sebagai kunci untuk diasumsikan bahwa persentase penghematan yang akan diperoleh memiliki nilai energi yang besar, meskipun untuk sementara belum diketahui berapa persen potensi hemat energi yang akan didapat. Apabila 
prosentase potensi yang diperoleh kecil, dikalikan dengan kapasitas yang besar, maka nilai yang diperoleh cukup signifikan. 2. Untuk memperoleh bobot pengguna energi terbesar, maka dilakukan stratifikasi objek peralatan.

3. Dari hasil stratifikasi diperoleh sebaran objek (peralatan pengguna energi) mulai pengguna energi terbesar hingga ke peralatan pengguna energi yang terkecil.

c. Metode $5 \mathrm{~W}+1 \mathrm{H}$

Metode ini digunakan untuk mencari akar permasalahan (sumber pemborosan yang dapat dikonversi menjadi potensi/peluang hemat energi) pada peralatan pengguna energi yang telah ditentukan dari hasil Pareto chart. Mekanisme pendekatan masalah menggunakan metode $5 \mathrm{~W}$ dan $1 \mathrm{H}$ adalah :

1. Where. Untuk menemukan dimana sumber yang berpotensi terjadinya pemborosan energi.

2. What. Untuk mengidentifikasi apa yang menyebabkan hingga terjadinya pemborosan energi.

3. Why. Untuk mengidentifikasi penyebab hal itu terjadi.

4. Who. Untuk mengidentifikasi siapa yang menjadi trigger (aktor utama) terjadinya potensi pemborosan energi pada peralatan yang sedang diteliti.

Analisa berdasarkan 5M (Man/Manpower, Machine, Material, Method, Mother Nature/lingkungan kerja).

5. When. Untuk mengidentifikasi waktu terjadinya masalah, dapat didiskusikan dengan operator apakah kejadiannya bersifat siklus, tidak menentu ataukah ada pengaruh dari proses operasi peralatan.

6. How. Bagaimana mengatasi akar masalah (sumber pemborosan yang dapat dikonversi menjadi potensi/peluang hemat energi) tersebut.

d. Metode Pengamatan dan Pengukuran

Untuk melihat efektifitas, dan performasi operasi peralatan yang ada. Data-data primer (pengamatan langsung dan hasil pengukuran) dan data sekunder (log-sheet dan hasil wawancara) sangat diperlukan untuk membantu di dalam analisa neraca massa dan energi.
Hasil pengukuran yang diambil berdasarkan pertimbangan peningkatan efektifitas dan efisiensi peralatan (menghindari terjadinya penurunan performa akibat efek kegiatan efisiensi energi).

\section{Tahapan Audit Energi}

Pelaksanaan audit energi dapat ditempuh melalui enam tahapan kegaiatan seperti yang disajikan pada Gambar 1.

a. Perencanaan dan Organisasi

Pada tahap ini dilakukan beberapa tindakan yang terdiri dari : penentuan tujuan audit, pemilihan anggota tim audit serta pemberian tanggung jawabnya, dan pemilihan instrumen yang diperlukan, serta penyiapan proposal kajian. Setelah dilakukan perencanaan yang matang, kemudian dilakukan pertemuan dengan Manajemen Puncak untuk mengumpulkan informasi umum, pemilihan area fous dan pembagian fasilitas pabrik menjadi bagian pelaksanaan atau cost center.

b. Pengkajian

Pengamatan singkat lapangan (walk through survey) yang sekaligus dapat melakukan in house training terhadap tim pendamping industri obyek. Anggota tim harus menyiapkan diagram alir proses area focus dan mengumpulkan data pemakaian energi dan data produksi yang diambilkan dari bagian atau cost center tertentu (form data sheet, data historis dan lain-lain) untuk menghitung losses melalui neraca massa dan energi.

c. Identifikasi Opsi

Penentuan penyebab kehilangan (losses) energi dilakukan pada tahap ini melalui pengolahan data dan evaluasi awal untuk mendapatkan neraca energi, neraca massa, intensitas energi serta mengidentifikasi peluang penghematan energi (PPE/opsi).

d. Analisis Kelayakan Opsi

Hasil identifikasi PPE/opsi selanjutnya dianalisis secara teknis, ekonomi dan lingkungan untuk menghasilkan daftar $\mathrm{PPE} /$ opsi berdasarkan besaran penghematan yang mungkin diperoleh. Kemudian menyiapkan proposal penerapan dan pemantauan untuk memperoleh persetujuan Manajemen Puncak. 


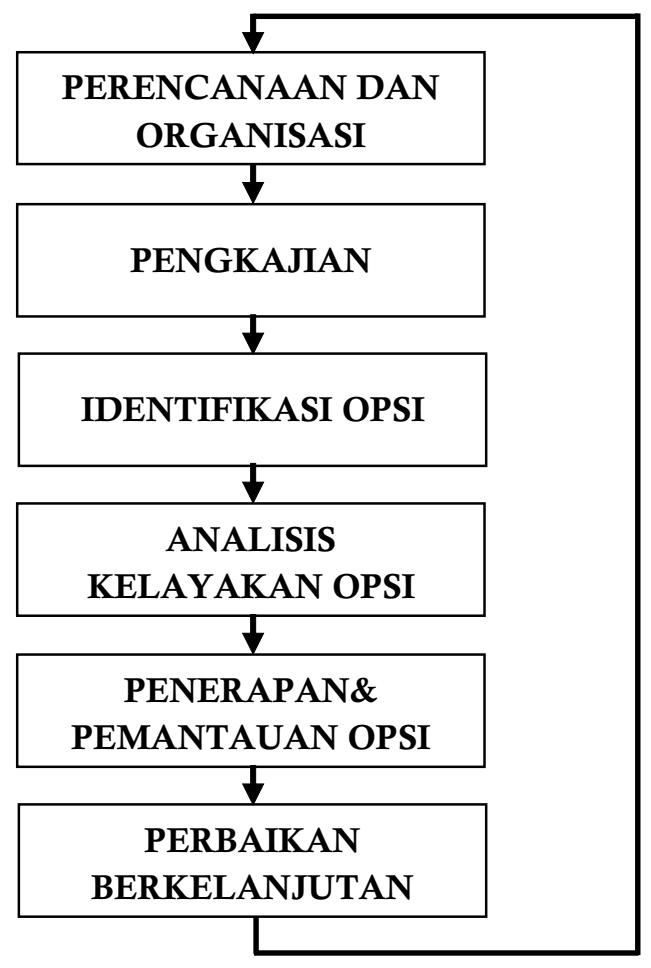

Gambar 1. Diagram alir tahapan kegiatan audit energi

\section{e. Penerapan dan Pemantauan Opsi}

Presentasi dan diskusi dengan Manajemen Puncak terhadap berbagai temuan dan hasil daftar PPE/opsi awal yang diperoleh. Langkah ini dilakukan sekaligus untuk klarifikasi berbagai data dan informasi sehingga pada saat pelaksanaan analisis rinci dilakukan dengan basis data dan informasi yang benar dan juga diterima oleh kedua pihak. Rekomendasi PPE (Opsi) selanjutnya diterapkan dan dipantau pelaksanaannya. Tim kemudian melakukan evaluasi dan analisis rinci terhadap penerapan PPE (opsi) yang diperoleh, serta menyusun laporan audit energi mencangkup rekomendasi PPE dan manajemen energi yang disampaikan kepada Manajemen Puncak.

\section{f. Perbaikan berkelanjutan}

Tim kemudian menyiapkan proposal lanjutan untuk memperoleh persetujuan manajemen puncak dan selalu melakukan perbaikan yang berkelanjutan.

\section{Konsumsi Energi Pada Pengolahan Karet}

1. Pengolahan lateks pekat

Pada prinsipnya pengolahan lateks pekat hanya memerlukan satu tahapan proses yaitu memisahkan air dari partikel karet. Pengolahan lateks pekat yang paling umum diterapkan adalah teknik sentrifugasi dengan sebagian besar konsumsi energi berupa energi listrik. Peralatan utama dalam pengolahan lateks pekat adalah mesin sentrifugal dengan motor induksi berkecepatan tinggi yang memerlukan energi lebih dari $90 \%$ dari energi yang digunakan. Mesin-mesin lain adalah pompa air, kipas listrik, pengaduk dan peralatan untuk pengolahan limbah. Hasil survei pada 31 pabrik di Thailand (Kementerian Energi Thailand, 2007) menunjukkan bahwa sebagian besar energi yang diperlukan adalah energi listrik (Gambar2). 


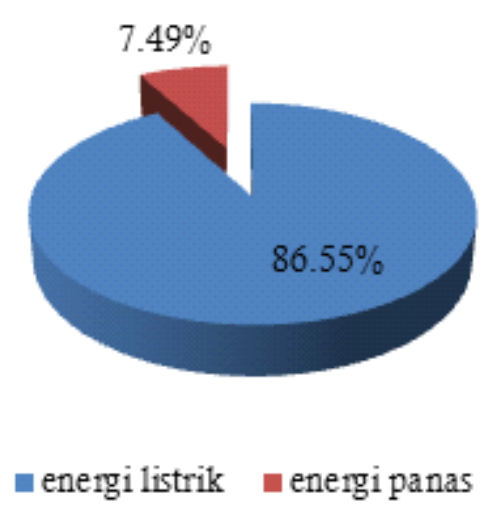

(a)

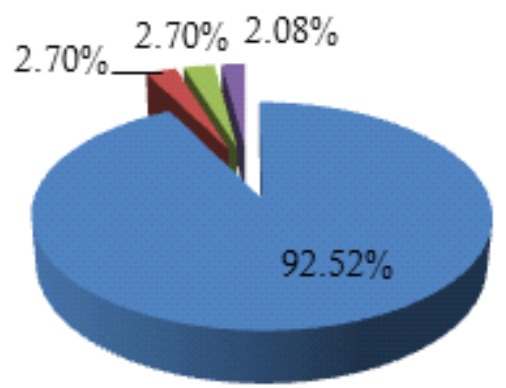

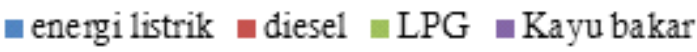

(b)

Gambar 2. a) Konsumsi energi listrik dan energi panas dalam produksi lateks pekat b) komposisi konsumsi energi berdasarkan jenis bahan bakar.

\section{Pengolahan sit}

Pengolahan sit angin tidak memerlukan banyak energi, cukup energi angin untuk mengeringkan sit, sedangkan Ribbed Smoked Sheet (RSS) atau Air Dried Sheet (ADS) memerlukan energi panas baik yang berasal dari udara panas untuk karet ADS maupun energi panas dari hasil pembakaran kayu karet untuk karet RSS.Pada pengolahan karet sit jenis ADS di Thailand, konsumsi energi spesifik (SEC/specific energy consumption) untuk pengeringan sit ADS yang menggunakan udara panas pada suhu $40-70{ }^{\circ} \mathrm{C}$ adalah $5,31-$ $12,10 \mathrm{MJ} / \mathrm{kg}$ air yang diuapkan (Tabel 1) (Ekphon etal., 2013).

Pada pengolahan sit jenis RSS memerlukan energi panas dan energi listrik untuk produksinya. Energi panas digunakan untuk kamar pengering yang biasanya berasal dari pembakaran kayu bakar. Energi listrik digunakan untuk sistem penerangan dan proses pumping. Hasil survei pada 18 pabrik sit di Thailand menunjukkan bahwa konsumsi energi terbesar adalah dari bahan bakar kayu karet untuk menghasilkan energi panas pada kamar pengering (Gambar 3).

Werapun et al. (2014) telah mendesain kamar pengering untuk sit asap dengan menggunakan kombinasi energi matahari dan listrik di Thailand. Konsumsi energi matahari pada kamar pengering ini sebesar $15-32 \%$ (Tabel 2). Sistem pengering menggunakan kombinasi energi pengering sinar matahari dan listrik dapat menghemat penggunaan energi listrik tetapi sistem ini memiliki kelemahan karena tergantung dengan kondisi cuaca sehingga sistem ini sulit untuk dikontrol.

Tabel 1. Konsumsi energi spesifik pada pengolahan ADS

\begin{tabular}{ccccc}
\hline $\begin{array}{c}\text { Suhu } \\
\text { pengeringan } \\
\left({ }^{\circ} \mathrm{C}\right)\end{array}$ & $\begin{array}{c}\text { Relative } \\
\text { Humidity }(\mathrm{RH}) \\
(\%)\end{array}$ & $\begin{array}{c}\text { Lama } \\
\text { pengeringan } \\
\text { (jam) }\end{array}$ & $\begin{array}{c}\text { Kecepatan } \\
\text { pengeringan } \\
(\mathrm{kg} / \mathrm{jam})\end{array}$ & $\begin{array}{c}\text { SEC } \\
(\mathrm{MJ} / \mathrm{kg} \\
\text { penguapan air })\end{array}$ \\
\hline \multicolumn{6}{c}{$\begin{array}{c}\text { Pengeringan dengan udara panas } \\
40\end{array}$} & 68 & 117,1 & 0,2954 & 5,31 \\
50 & 79 & 89,1 & 0,3616 & 11,45 \\
60 & 73 & 48 & 0,4736 & 12,10 \\
70 & 66 & 30 & 0,8635 & 9,85 \\
\hline 29 & 70 & Pengeringan konvensional (kontrol) & - \\
30 & 66 & 226 & 0,1019 & - \\
30 & 67 & 152,1 & 0,1821 & - \\
\hline
\end{tabular}

Sumber: Ekphon et al., 2013 


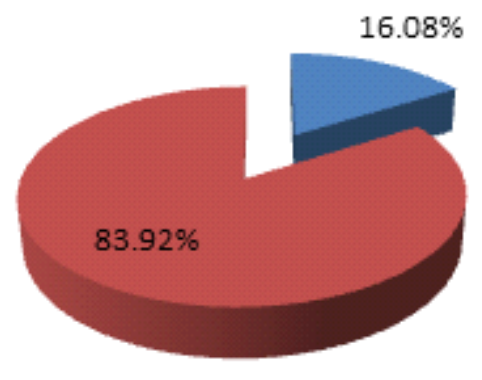

Шenergi listrik $\quad$ energi panas

a

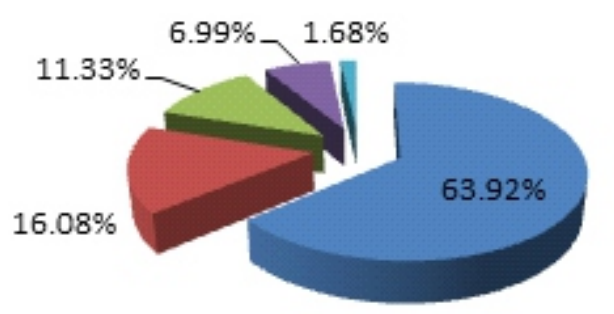

Kayu bakar $\mathbf{\square}$ listrik diesel
neavy oil $\quad$ ke rosene

b

Gambar 3. a) Konsumsi energi listrik dan energi panas dalam produksi sit asap, dan

b) komposisi konsumsi energi berdasarkan jenis bahan bakar

Tabel 2. Persentase penggunaan energi dalam sistem pengeringan

\begin{tabular}{cccccc}
\hline $\begin{array}{c}\text { Rck ncp_rs } p \\
\left({ }^{\circ} \mathrm{C}\right)\end{array}$ & $\begin{array}{c}\text { Energi } \\
\text { listrik } \\
(\mathrm{kWh})\end{array}$ & $\begin{array}{c}\text { Energi } \\
\text { matahari } \\
(\mathrm{kWh})\end{array}$ & $\begin{array}{c}\text { Persentasi } \\
\text { penggunaan energi } \\
\text { listrik }(\%)\end{array}$ & $\begin{array}{c}\text { Persentase } \\
\text { penggunaan energi } \\
\text { matahari }(\%)\end{array}$ & $\begin{array}{c}\text { Total } \\
(\mathrm{kWh})\end{array}$ \\
\hline \multicolumn{7}{c}{ Kamar pengering menggunakan energi matahari dan listrik } \\
40 & 12,55 & 5,00 & 71,50 & 28,50 & 17,55 \\
50 & 11,66 & 5,59 & 67,58 & 32,42 & 17,25 \\
60 & 20,05 & 3,80 & 84,05 & 15,95 & 23,85 \\
\hline 50 & Kamar pengering hanya menggunakan energi listrik \\
\hline
\end{tabular}

Sumber: Werapun et al. (2014)

Sementara itu pada pengolahan sit asap di Indonesia, penggunaan energi pada ruang pengering (menggunakan bahan bakar kayu karet dengan nilai heating value $27,667 \mathrm{~kJ} / \mathrm{kg}$ dan moisture $23,8 \% \mathrm{wb}$ ) menunjukkan input energi $100 \%$, hanya $24 \%$ energi yang termanfaatkan, sedangkan $7 \%$ energi tersimpan pada dinding, pintu, lantai dan atap. Energi yang hilang ke lingkungan melalui kontruksi dinding, pintu dan atap sebanyak $48 \%$. Sisanya $20 \%$ energi yang tidak terukur yang hilang melalui ventilasi, cerobong asap dan lain-lain. Efisiensi penggunaan energi kamar pengering sangat rendah karena konstruksi bahan bangunan. Konstruksi bangunan kamar pengering umumnya terdiri dari dinding dari batu-bata, atap dari asbes, pintu dari baja dan tungku dari batu-bata, serta tidak ada sistem isolasi. Padahal konstruksi bangunan memberikan konstribusi dalam penggunaan energi yang optimal karena perpindahan panas konduksi, konveksi dan radiasi (Ediati dan Jajang, 2010).
3. Pengolahan karet remah

Karet remah adalah karet kering yang proses pengolahannya melalui tahap peremahan. Bahan baku berasal dari lateks yang telah diolah menjadi koagulum atau sleb. Pengolahan karet remah memerlukan energi listrik dan energi panas. Energi listrik diperlukan untuk proses mesin milling, compressing dan shredding, sedangkan energi panas digunakan untuk tahap pengeringan dimana diesel dibakar untuk menghasilkan udara panas yang memiliki suhu $100-120^{\circ} \mathrm{C}$. Hasil survey pada 34 pabrik di Thailand menunjukkan bahwa komposisi konsumsi energi listrik dan energi panas untuk menghasilkan karet remah memiliki jumlah yang hampir sama. Energi listrik adalah energi yang paling banyak digunakan selain heavy oil, LPG, diesel, gasoline dan benzene.

Hasil survei pengolahan karet remah di Indonesia dapat dilihat pada Tabel 3. Konsumsi energi terbesar adalah energi listrik 
dimana energi ini sebagian besar digunakan untuk proses membersihkan dan memperkecil ukuran bokar, serta proses penggilingan dengan menggunakan hammer mill (175 HP) dengan kapasitas mesin $4000 \mathrm{~kg} / \mathrm{jam}$.

Konsumsi energi total pada produksi karet remah adalah $3,06272 \mathrm{MJ} / \mathrm{kg}$ karet kering(Utomo et al. , 2010).

\section{Audit Energi Dalam Pengolahan Karet Remah}

\section{Intensitas Energi}

Intensitas energi merupakan indikator yang menggambarkan hubungan antara konsumsi energi dan ekonomi, serta konsumsi energi dan penduduk. Intensitas energi dapat

Tabel 3. Konsumsi energi dalam produksi SIR 20

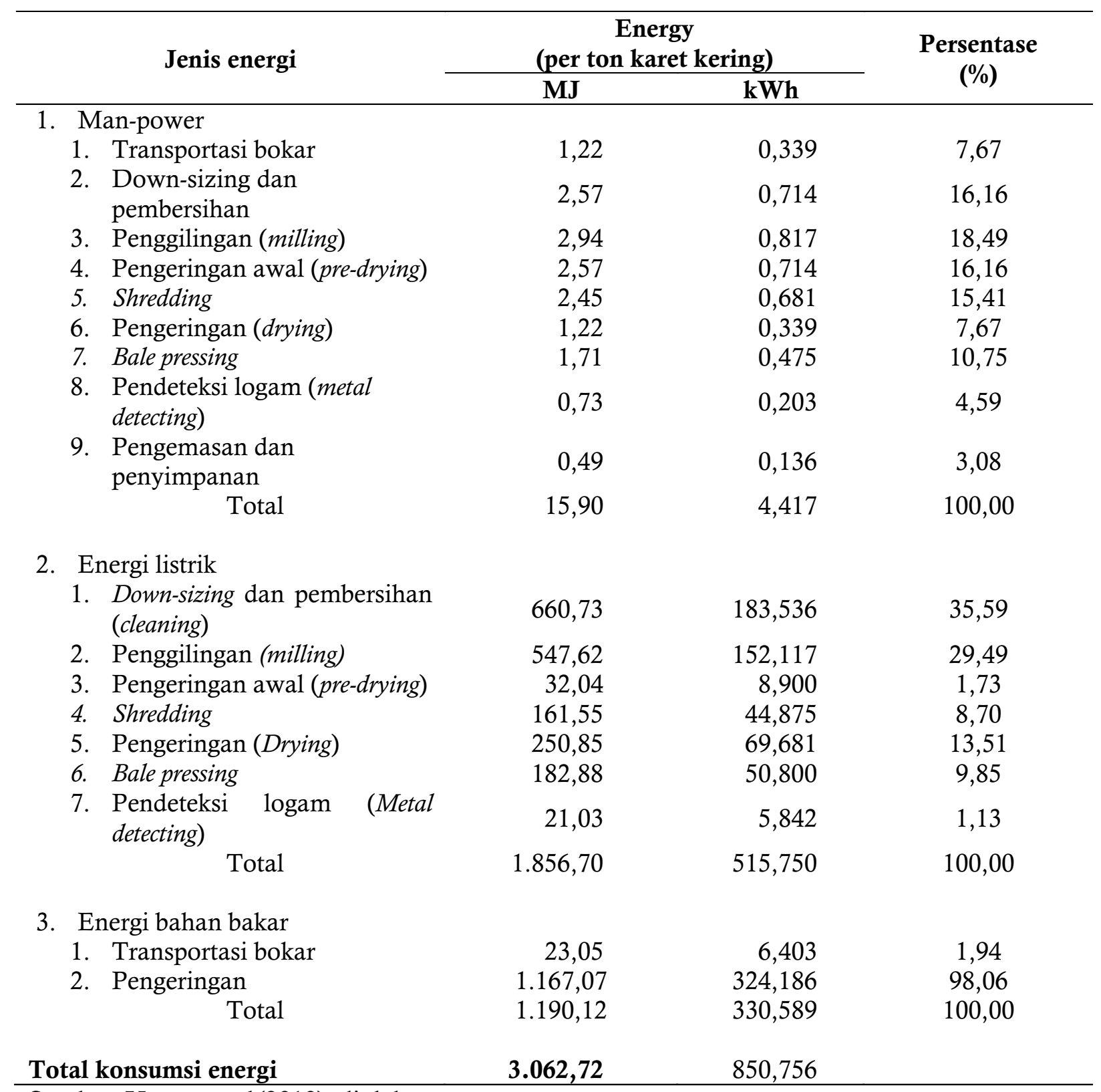

Sumber: Utomo et al.(2010), diolah 
digunakan sebagai suatu ukuran efisiensi energi dari ekonomi suatu negara. Semakin tinggi intensitas energi menunjukkan suatu harga atau biaya yang tinggi untuk mengubah energi kepada Produk Domestik Bruto (PDB), sedangkan semakin rendah intensitas energi menunjukkan suatu harga atau biaya yang rendah untuk mengubah energi kepada PDB (Kementerian energi dan sumber daya mineral, 2012). Nilai intensitas energi juga dapat menggambarkan pengaruh atau dampak penggunaan energi terhadap lingkungan (ecoefficiency), dimana semakin tinggi nilai intensitas energi maka semakin kurang nilai efisiensi lingkungan (eco-efficiency) dan kerusakan sumber daya alam seperti bahan bakar fosil (Maulina, 2009).

Kebutuhan energi untuk memproduksi karet remah dengan kapasitas produksi 45.240 ton adalah $26.257 .005 \mathrm{kWh}$. Terdapat korelasi antara konsumsi energi (Y) dan produksi (X), korelasi tersebut adalah $: \mathrm{Y}=455+145 \mathrm{X} ; \mathrm{r}_{\mathrm{XY}}=$ Besarnya intensitas energi pada suatu industri berfluktuatif. Suatu industri dikatakan efisien jika intensitas energi maksimum adalah 179 $\mathrm{kWh} /$ ton atau $153 \mathrm{Mcal} / \mathrm{ton}$, intensitas minimum adalah $126 \mathrm{kWh} /$ ton atau 108 $\mathrm{Mcal} /$ ton, dan rataan intensitas adalah 136 $\mathrm{kWh} /$ ton atau $116 \mathrm{Mcal} /$ ton. Jika nilai intensitas suatu industri melebihi intensitas energi maksimum maka ini menunjukkan bahwa penggunaan energi pada industri tersebut tidak efektif sehingga memiliki potensi untuk penghematan energi.

Berdasarkan hasil audit energi pada salah satu pabrik karet remah SIR 20 di Indonesia (Utomo et al., 2010), dimana besarnya konsumsi energi adalah 3062,72 MJ/ton karet kering atau 850,756 $\mathrm{kWh} /$ ton karet kering. Nilai konsumsi energi ini juga menunjukkan intensitas energi dari pabrik karet remah tersebut. Besarnya intensitas pabrik karet remah tersebut ternyata lebih tinggi $(850,756>$ $179 \mathrm{kWh} /$ ton). Ini menunjukkan bahwa pabrik karet remah tersebut belum efisien dalam pengolahan energi.

Faktor -faktor yang mempengaruhi nilai intensitas energi adalah :
1) Pola operasi peralatan, 2) Pola pemakaian motor listrik dengan efisiensi rendah, 3) Pemilihan bahan baku, dan 4) Penerapan sistem manajemen energi.

Potensi penghematan energi dalam pengolahan karet remah

\section{a. Peralatan utama penggunaan energi}

Peralatan utama dalam pengolahan karet remah seperti mesin breaker, hammermill, macerator dan creper, dapat dilakukan penghematan dengan cara :

1. Menjaga $\mathrm{KVA}_{\text {maks }}<361 \mathrm{KVA}$

KVA adalah satuan bagi daya yang dihasilkan oleh tenaga listrik, yaitu hasil kali tegangan listrik (volt) dengan kuat arus (ampere)

2. Perbaikan daya listrik

Daya didefinisikan sebagai laju energi yang dibangkitkan atau dikonsumsi. Perbaikan faktor daya dapat diartikan sebagai usaha untuk membuat faktor daya/cos mendekati 1 (satu). Untuk memperbaiki faktor daya dari suatu beban yang mempunyai faktor daya yang rendah, perlu dipasang kapasitor pada masingmasing beban atau secara tersentralisir melalui kapasitor bank. Dengan pemasangan kapasitor tersebut, selain untuk memperbaiki faktor daya juga dapat memperbaiki pengaturan tegangan dan meningkatkan efisiensi transformator (S.P. Purbaningrum, 2014). Perbaikan faktor daya juga dapat mengunakan filter harmonisa (Supri Hardi dan Yaman, 2013)

3. Efisiensi pada sistem pengering dapat dilakukan dengan penggunaan sistem pengering bertingkat dan menggabungkan berbagai tipe pengering (Law dan Mujumdar, 2009).

\section{b. Peralatan utilitas}

Peralatan utilitas berfungsi untuk menunjang kegiatan produksi seperti pompa, boiler, dan conveyer juga berpotensi dilakukan penghematan dengan cara :

(1) Menyeimbangkan beban, dan

(2) Pemasangan filter 


\section{c. Sistem manajemen energi}

Manajemen energi merupakan program terpadu yang direncanakan dan dilaksanakan secara sistematis untuk memanfaatkan sumberdaya energi secara efektif dan efisien dengan melakukan perencanaan, pencatatan, pengawasan dan evaluasi secara kontinu tanpa mengurangi kualitas produksi/pelayanan (Purbaningrum, 2014).

Sistem Manajemen Energi (SME) telah digunakan secara global dan menjadi standar sertifikasi internasional bagi usaha pengelolaan energi melalui ISO 50001. Proses SME menurut ISO 5001 mengikuti Plan-DoCheck-Act (PDCA)

- Plan: Melakukan review energi dan menetapkan landasan, indikator kinerja energi (Energy performance indicator), tujuan, sasaran dan rencana aksi yang diperlukan untuk memberikan hasil yang sesuai dengan peluang untuk meningkatkan kinerja energy (energy performance) dan kebijakan energi organisasi.

- Do : Mengimplementasikan rencana aksi pengelolaan energi.

- Check : Memonitor dan mengukur proses dan karakteristik proses operasi yang menentukan kinerja energi terhadap kebijakan energi dan tujuan dari manajemen energi organisasi, serta melaporkan hasil.
Act : Mengambil tindakan untuk terus meningkatkan kinerja energi dan sistem manajemen energi.

Pelaksanaan sistem manajemen energi harus diimplementasikan secara konsisten dan berkesinambungan.

\section{Konversi Energi}

Potensi energi baru dan terbarukan di Indonesia terdiri dari panas bumi, tenaga air, biomassa, energi angin, surya, uranium, gas metana batubara dan shale gas (Tabel 4). Pemanfaatan energi baru seperti panas bumi, tenaga air dan penggunaan biomassa limbah kelapa sawit terbukti juga dapat menurunkan emisi rumah kaca (Juniah, 2008).

Penggunaan bahan bakar minyak (BBM) sebagai sumber energi di Indonesia saat ini masih cukup dominan. Bahan bakar minyak yang termasuk dalam energi tidak terbarukan ini ketersediaannya akan semakin terbatas dan cenderung semakin mahal. Dengan investasi dan biaya operasi yang juga cukup mahal, walaupun sudah didukung teknologi dan infrastruktur yang sangat baik, untuk masa mendatang penggunaan bahan bakar minyak diduga akan semakin kurang ekonomis. Selain itu, penggunaan bahan bakar minyak juga menjadi salah satu penyebab polusi dan timbulnya efek gas rumah kaca yang ditandai dengan meningkatnya suhu di permukaan bumi.

Tabel 4. Sumber energi baru dan terbarukan di Indonesia

\begin{tabular}{lcc}
\hline \multicolumn{1}{c}{ Sumber energi } & Potensi & Kapasitas terpasang \\
\hline Panas bumi (geothermal) & $16.502 \mathrm{MW}$ & $1.341 \mathrm{MW}$ \\
& (cadangan) & (sampai mei 2013) \\
Tenaga air (hydro) & $\begin{array}{c}75.000 \mathrm{MW} \\
\text { (sumberdaya) }\end{array}$ & $7.059 \mathrm{MW}$ \\
Mini-mikrohidro & $769,7 \mathrm{MW}$ & $512 \mathrm{MW}$ \\
(mini-micro hydro) & (sumberdaya) & $1.364 \mathrm{Mwe}$ \\
Biomassa (biomass) & $13.662 \mathrm{Mwe}$ & $(75,5 \mathrm{Mwe}$ (on grid) \\
Energi surya (solar energy) & $4,80 \mathrm{kWh} / \mathrm{m}^{2} / \mathrm{hari}$ & $1,78 \mathrm{MW}$ \\
Energi angin (wind energi) & $3-6 \mathrm{~m} / \mathrm{s}$ & $30 \mathrm{MW}$ \\
Uranium & $3000 \mathrm{MW}$ & \\
Gas metana batubara & $453 \mathrm{TSCF}$ & \\
(coal bed methane) & (sumberdaya) & \\
Shale gas & $574 \mathrm{TSCF}$ & \\
\hline
\end{tabular}

Sumber: Sugiyono et al., 2014 
Untuk mengurangi ketergantungan dan dampak negatif penggunaan bahan bakar minyak, perlu dilakukan konversi sumber energi. Pemerintah Republik Indonesia saat ini sudah melakukan konversi sumber energi terutama untuk rumah tangga dari bahan bakar minyak ke gas bumi. Beberapa jenis gas yang banyak digunakan sebagai sumber energi antara lain Liquified Petroleum Gas (LPG) dan Compressed Natural Gas (CNG) atau yang dikenal sebagai bahan bakar gas (BBG). Komposisi BBG terdiri atas $85 \% \mathrm{CH}_{4}, 10 \% \mathrm{~N}_{2}$ dan $\mathrm{CO}_{2}$ serta etana, propana dan butana. Gas alam di Indonesia memiliki cadangan sebesar 151 TSCF yang terdiri atas 103 TSCF cadangan terbukti dan 47 TSCF cadangan potensial. Angka ini menunjukkan bahwa potensi gas alam di Indonesia masih cukup potensial. Tetapi dengan eksploitasi secara besar-besaran cadangan gas alam diprediksi akan terus mengalami penurunan.

Penggunaan gas alam sebagai sumber energi saat ini cenderung mengalami peningkatan seiring dengan semakin mahalnya harga bahan bakar minyak. Dalam kegiatan eksploitasi dan produksinya, sumber energi gas alam di Indonesia sudah didukung oleh teknologi dan infrastruktur yang relatif baik walaupun teknologinya masih tergantung dengan luar. Selain itu, nilai investasi dan biaya operasinya juga relatif mahal. Hal ini akan berakibat pada nilai jual gas alam yang akan semakin mahal. Dampak penggunaan bahan bakar gas relatif lebih baik dibandingkan bahan bakar minyak karena lebih bebas polusi dan bersifat reduktif terhadap efek rumah kaca.

Sumber energi alternatif yang saat ini juga sudah banyak digunakan terutama untuk pembangkit listrik adalah batubara. Sayangnya batubara yang termasuk sumber energi fosil (energi tidak terbarukan) juga mempunyai keterbatasan. Dengan eksploitasi besarbesaran seperti sekarang, cadangan batubara di Indonesia terus menipis. Teknologi untuk memproduksi batubara (eksploitasi) dan menggunaan batubara sudah cukup baik. Sebagai salah satu negara produsen, Indonesia sudah mampu menguasai teknologi eksploitasi batubara dan tidak terlalu tergantung dengan negara luar. Berbeda seperti bahan bakar minyak dan gas alam, biaya investasi dan biaya operasinya dinilai masih relatif lebih murah. Akibatnya harga batubara juga masih lebih murah dibandingkan bahan bakar minyak dan gas alam. Penggunaan batubara sebagai sumber energi memberikan dampak negatif bagi lingkungan. Batubara termasuk salah satu sumber polusi dan menjadi penyebab timbulnya efek rumah kaca.

Selain ketiga sumber energi di atas, di Indonesia masih terdapat sumber energi baru dan terbarukan yang ketersediaan cukup berlimpah. Potensi energi baru dan terbarukan di Indonesia terdiri dari panas bumi, tenaga air, biomassa, energi angin, surya, uranium, gas metana batubara dan shale gas (Tabel 4). Pemanfaatan energi baru seperti panas bumi, tenaga air dan penggunaan biomassa limbah kelapa sawit terbukti juga dapat menurunkan emisi rumah kaca (Juniah, 2008). Bahkan penerapan Clean Development Mechanism (CDM) oleh PT. Pupuk Kaltim melalui proyek desalination unit dengan teknologi reverse osmosis yang memanfaatkan air laut telah berhasil mendapatkan Certified emission reduction (CER) berpotensi untuk penjualan carbon dari pengurangan emisi $\mathrm{Co}_{2}$ (Juniah,2008).

Sejak tahun 2006, Pemerintah Indonesia telah menerbitkan peraturan dan kebijakan untuk penyediaan dan pemanfaatan Bahan Bakar Nabati (bio-oil) sebagai bahan bakar pengganti minyak. Bio-oil merupakan bahan bakar cair yang berasal dari biomassa seperti kayu, limbah pulp dan kertas, serbuk gergaji, tandan kelapa sawit kosong dan limbah pertanian jagung yang dapat diproses secara pyrolisis (Dahlan, 2008). Selain limbah pertanian, bio-oil juga dapat diproleh dari hasil perkebunan seperti singkong dan tebu yang akan menghasilkan bioetanol (Priyanto, 2009).

Selain bahan bakar cair, biomassa dapat dikonversi menjadi bahan bakar gas melalui proses gasifikasi yang biasa disebut dengan biogas. Biomassa yang dapat digunakan sebagai sumber bahan bakar gas diantaranya tempurung kelapa sawit, limbah perkebunan 
karet seperti tunggul, kayu, ranting, scrap dan tatal, serta limbah pabrik karet (Vidian dan Fikri, 2008 ; Suwardin, 2011).Penggunaan biomassa dalam pengolahan karet oleh pabrik karet remah di beberapa pabrik di Indonesia sudah diimplementasikan sebagai mana dilaporkan Vachlepi dan Suwardin (2014).

Ketersediaan sumber energi terbarukan di Indonesia yang berlimpah ini sayangnya masih belum diikuti oleh penyediaan infrastruktur yang baik. Untuk kegiatan produksi sumber energi ini infrastruktur pendukungnya relatif masih sangat kurang. Padahal teknologi produksinya sudah bisa dikembangkan sendiri dan tidak tergantung dengan negara luar. Tidak seperti bahan bakar minyak dan gas alam, biaya investasi dan biaya operasionalnya juga terbilang cukup murah. Penggunaan sumber energi baru dan terbarukan ini juga tidak memberikan dampak negatif terhadap lingkungan. Sumber energi ini tidak menimbulkan polusi dan efek rumah kaca yang tidak baik bagi lingkungan. Penggunaan energi hubungannya dengan parameter pertimbangan pemilihannya ditampilkan pada Tabel 5.

\section{Kesimpulan}

Audit energi perlu dilakukan untuk setiap produksi sebagai upaya untuk meningkatkan efisiensi melalui aplikasi opsi penghematan. Dalam implementasi audit energi diperlukan komitmen dari manajemen puncak dengan aplikasi sistem manajemen energi yang konsisten dan berkesinambungan. Nilai intensitas energi pada pengolahan karet belum efektif sehingga perlu dilakukan penghematan energi dengan cara penghematan energi pada peralatan utama pengguna energi, penghematan energi pada peralatan utilitas, dan penerapan sistem manajemen energi. Konversi bahan bakar minyak (BBM) kepada penggunaan sumber energi yang terbarukan dan ramah lingkungan pada pengolahan karet (karet remah) dapat dilakukan dalam rangka penghematan energi. Konversi ini dapat berupa bahan bakar gas (BBG) yang bersumber dari biomassa (limbah) atau bahan bakar cair seperti bioetanol atau biofuel.

Tabel 5. Hubungan jenis energi dan parameter pilihan sumber energi

\begin{tabular}{|c|c|c|c|c|c|c|c|c|}
\hline \multirow{2}{*}{\multicolumn{2}{|c|}{ Parameter }} & \multicolumn{7}{|c|}{ Jenis Energi } \\
\hline & & \multirow{2}{*}{$\begin{array}{c}\text { BBM } \\
\text { terbatas } \\
\text { baik }\end{array}$} & \multirow{2}{*}{$\begin{array}{c}\text { LNG } \\
\text { cukup } \\
\text { baik }\end{array}$} & \multirow{2}{*}{$\begin{array}{c}\text { LPG } \\
\text { cukup } \\
\text { baik }\end{array}$} & \multirow{2}{*}{$\begin{array}{c}\text { Batubara } \\
\text { terbatas } \\
\text { baik }\end{array}$} & \multirow{2}{*}{$\begin{array}{c}\begin{array}{c}\text { Biofuel } \\
\text { biosolar }\end{array} \\
\text { potensial } \\
\text { kurang }\end{array}$} & \multirow{2}{*}{$\begin{array}{c}\text { Biogas } \\
\text { potensial } \\
\text { kurang }\end{array}$} & \multirow{2}{*}{$\begin{array}{c}\text { Biomassa } \\
\text { berlimpah } \\
\text { Kurang }\end{array}$} \\
\hline Ketersediaan & $\begin{array}{c}\text { Volume } \\
\text { Infrastruktur }\end{array}$ & & & & & & & \\
\hline Teknologi & $\begin{array}{l}\text { Kehandalan } \\
\text { Kemandirian }\end{array}$ & $\begin{array}{c}\text { baik } \\
\text { dependen }\end{array}$ & $\begin{array}{c}\text { baik } \\
\text { dependen }\end{array}$ & $\begin{array}{c}\text { baik } \\
\text { dependen }\end{array}$ & $\begin{array}{c}\text { baik } \\
\text { mandiri }\end{array}$ & $\begin{array}{c}\text { baik } \\
\text { mandiri }\end{array}$ & $\begin{array}{l}\text { cukup } \\
\text { mandiri }\end{array}$ & $\begin{array}{c}\text { baik } \\
\text { Mandiri }\end{array}$ \\
\hline Finansial & $\begin{array}{c}\text { Investasi } \\
\text { Biaya Operasi }\end{array}$ & $\begin{array}{l}\text { mahal } \\
\text { mahal }\end{array}$ & $\begin{array}{l}\text { mahal } \\
\text { mahal }\end{array}$ & $\begin{array}{l}\text { mahal } \\
\text { mahal }\end{array}$ & $\begin{array}{l}\text { sedang } \\
\text { sedang }\end{array}$ & $\begin{array}{l}\text { murah } \\
\text { murah }\end{array}$ & $\begin{array}{l}\text { murah } \\
\text { murah }\end{array}$ & $\begin{array}{l}\text { murah } \\
\text { Murah }\end{array}$ \\
\hline Lingkungan & $\begin{array}{c}\text { Polusi } \\
\text { Efek rumah kaca }\end{array}$ & $\begin{array}{l}\text { polutif } \\
\text { negatif }\end{array}$ & $\begin{array}{l}\text { bebas } \\
\text { reduksi }\end{array}$ & $\begin{array}{l}\text { bebas } \\
\text { reduksi }\end{array}$ & $\begin{array}{l}\text { polutif } \\
\text { negatif }\end{array}$ & $\begin{array}{l}\text { bebas } \\
\text { reduksi }\end{array}$ & $\begin{array}{l}\text { bebas } \\
\text { reduksi }\end{array}$ & $\begin{array}{l}\text { bebas } \\
\text { reduksi }\end{array}$ \\
\hline
\end{tabular}




\section{Daftar Pustaka}

Adiprama, T.R. dan Ciptomulyono, U. (2012). Audit energi dengan pendekatan metode MCDM PROMETHEE untuk konservasi serta efisiensi listrik di rumah sakit haji Surabaya. Jurnal Teknik POMITS, 1(1), 1-6.

Anindhita, A.S., Sidik Boedoyo, M.S., dan Adiarso. (2014). Outlook energy Indonesia 2014 : Pengembangan energi untuk mendukung program substitusi BBM. Jakarta : Pusat Teknologi Pengembangan Sumberdaya Energi - Badan Pengkajian dan Penerapan Teknologi.

Ayuni, M. (2012). Kebijakan konservasi energi. Workshop Efisiensi Energi di Sektor Industri Kecil dan Menengah (IKM), Jakarta, Maret 2012.

Dahlan, M.H. (2008). Konversi biomassa menjadi bio oil sebagai sumber energi. Prosiding Seminar Nasional AVOER Fakultas Teknik Universita Sriwijaya. Palembang, Mei 2008.

Ediati, R. dan Jajang. (2010). Mathematical model of smoking time temperature effect on ribbed smoke sheet quality. World Academy of Science, Engineering and Technology, 4(21), 644-648.

Ekphon, A., Ninchuewong, T., Tirawanichakul, S., and Tirawanichakul, Y. (2013). Drying model, shrinkage and energy consumption evolution of air dried sheet rubber drying system for small enterprise. Advanced materials research, 622623, 1135-1139.

Fukushima, N. (2002). Technologies to improve energy efficiency and energy management methods in factories. Tokyo : Energy Conservation Center Japan (ECCJ).

Hardi, S. dan Yaman. (2013). Peredaman harmonisa dan pebaikan faktor daya aplikasi beban rumah tangga. Jurnal Litek, 10(1), 35-42.

Juniah, R. (2008). Alternatif pemanfaatan sumber energi terbarukan dalam skema clean development mechanism : Suatu Kajian Pustaka. Prosiding Seminar Nasional AVOER Fakultas Teknik Universita Sriwijaya. Palembang, Mei 2008.
Kementerian Perindustrian. (2011). Pedoman teknis audit energi dalam implementasi konservasi energi dan pengurangan emisi $\mathrm{CO}_{2} \mathrm{di}$ sektor industri (Fase 1). Jakarta : Kementerian Perindustrian.

Kementerian Energi dan Sumber Daya Mineral. (2012). Kajian Indonesia energi outlook. Jakarta : Pusat Data dan Informasi Energi dan Sumber Daya Mineral.

Kementerian Energi Thailand. (2007). Project on studying of energy efficiency index in rubber industry. Departemen Pengembangan Energi Alternatif dan Efisiensi. Bangkok : Kementerian Energi Thailand.

Law, C.L., dan Mujumdar, A.S. (2009). Energy issue in industrial drying. Procceeding Sriwijaya International Seminar on Science and Technology (SISSET 2009). The National Strategic Prime Research (New \& Renewable Energy Development). Palembang, 2009.

Marzuki, A. dan Rusman. (2012). Audit energi pada bangunan direksi PT Perkebunan Nusantara XIII (Persero). Vokasi, 8(3), 186196.

Maulina, S. (2009). Eco-efficiency indicators in latex concentrate processing : Energy intensity. Procceeding Sriwijaya International Seminar on Energy Science and Technology SISSET 2009. Palembang, 2009.

Mulyadi, Y., Rizki, A., dan Sumarto. (2013). Analisis audit energi untuk pencapaian efisiensi penggunaan energi di gedung FPMIPA JICA Universitas Pendidikan Indonesia. Electrans, 12(1), 81-88.

Palaloi, S. (2005). Audit energi sistem kelistrikan di pabrik gula. Jurnal ilmiah Purbaningrum, S. P. (2014). Audit energi dan analisis peluang penghematan konsumsi energi listrik pada rumah tangga. Media Mesin, 15(1), 26-33.

Priyanto, U. (2000). Development and prospect of biofuel in Indonesia. Proceedings. Sriwijaya international seminar on energy science and technology (SISEST). Palembang, 2000.

Raharjo, B. A., Wibawa, U., dan Suyono, H. (2014). Studi analisis konsumsi dan penghematan energi di PT. Krebet Baru I. Jurnal Mahasiswa TEUB, 1(1), 1-6. 
Utomo, T.P., Hasanudin, U., and Suroso, E. (2010). Comparative study of low and highgrade crumb rubber processing energy. Proceedings of the world cogress on engineering 2010, vol III, London, June - July 2010.

Save Energy. (2012, Maret 12). 2 kategori indikator energi. Diakses dari http://saveenergy-info.blogspot.com

Suwardin, D. (2011). Pemanfaatan limbah perkebunan karet dan pabrik karet remah sebagai sumber bioenergi. Warta Perkaretan, 30(2), 88-94.

Vachlepi, A dan Suwardin, D. (2014). Pengeringan karet remah berbasis sumber energi biomassa. Warta Perkaretan, 33(2), 103-112.
Vidian, F dan Fikri. (2008). Pemanfaatan tempurung kelapa sawit menjadi bahan bakar gas melalui teknologi gasifikasi. Prosiding Seminar Nasional AVOER Fakultas Teknik Universitas Sriwijaya, Palembang, Mei 2008.

Werapun, W., Pianroj, Y., Jumrat, S., and Kongchana, P. (2014). Drying kinetics of natural rubber sheets by using a hybrid solar-electric dryer with force convection. The Journal of Industrial Technology, 10(3), 85-95. 